\title{
Pesticide Risk Reduction of Vegetable Farmers: A Case Study in Vietnam
}

\author{
Nguyen Van Song1, Nguyen Thi Thuy ${ }^{1 *}$, Nguyen Cong Tiep" ${ }^{1}$, Thai Van Ha², Nguyen Dang Que ${ }^{3}$, \\ Nguyen Thi Xuan Huong4
}

${ }^{1}$ Vietnam National University of Agriculture, Hanoi, Vietnam

${ }^{2}$ National Academy of Education Management (NAEM), Hanoi, Vietnam

${ }^{3}$ National Academy of Public Administration (NAPA), Hanoi, Vietnam

${ }^{4}$ Vietnam National University of Forestry (VNUF), Hanoi, Vietnam

Email: ^nguyenthithuy5590@gmail.com

How to cite this paper: Van Song, N., Thuy, N.T., Tiep, N.C., Van Ha, T., Que, N.D. and Huong, N.T.X. (2021) Pesticide Risk Reduction of Vegetable Farmers: A Case Study in Vietnam. Journal of Environmental Protection, 12, 1055-1068. https://doi.org/10.4236/jep.2021.1212062

Received: November 8, 2021

Accepted: December 11, 2021

Published: December 14, 2021

Copyright (อ 2021 by author(s) and Scientific Research Publishing Inc. This work is licensed under the Creative Commons Attribution International License (CC BY 4.0).

http://creativecommons.org/licenses/by/4.0/

\section{(c) (i) Open Access}

\begin{abstract}
A survey was carried out on farmers cultivating vegetables in Gia Lam district, Hanoi city, Vietnam to investigate their practice in reducing pesticide risks in their farming. Pesticides were an important input in the production there, but the risks of pesticides in recent years had been insignificant. Research results showed that the majority of farmers had relatively well implemented various solutions to reduce pesticides risks in their production, including actively using alternative pest management (IPM) solutions, using biological pesticides, using pesticides properly according to the 4-right pesticide use principle, using labour protection while spraying, and applying treatment measures after spraying. The study suggested solutions to reduce and avoid pesticide risks.
\end{abstract}

\section{Keywords}

Pesticides, Risk Reduction, Vegetable Farming

\section{Introduction}

Pesticides are the substances or mixtures of substances that are used intentionally in order to control or destroy unwanted forms of life or organisms with the aim of protecting crops and plants [1]. Using pesticides in agricultural production is one of the most important measures to help limit the reduction of agricultural output due to pests and diseases, helping to create a large amount of agricultural products at reasonable prices year round, meeting the growing needs of people around the world [2]. In other words, pesticides are an economical, effective and labour-saving pest management method that are widely applied in 
most fields of agricultural production [3]. Various types of pesticides have been used to protect crops for centuries [1]. However, an excess use and misuse of pesticides in agricultural production often lead to severe impacts on human health and the environment [4]. Farmers, the direct users, are easily exposed to pesticides [5]. Exposure to pesticides is generally through contact with the skin, ingestion, or inhalation [6].

Pesticide risks are considered as the potential for a pesticide to cause harm as determined by environmental conditions and preventive actions [7]. Pesticide risks to farmers are the risks that often occur during the time they are spraying pesticides and working on the fields [3]. [8] defines pesticide risk as the result of a toxic hazard and exposure to that hazard (including intensity and duration of exposure). Therefore, pesticide risk reduction will be achieved by reducing toxic hazard and/or reducing exposure [3]. Reduction of toxic hazard is attained by choosing less hazardous products, and reduction of exposure is obtained by using less pesticides, better spraying methods, and more complete protective equipment.

Gia Lam district, Hanoi city is a delta district with fertile soil, favourable natural conditions with a humid monsoon climate suitable for intensive cultivation of wet rice, vegetables, fruit trees and short-term cash crops; in which, the vegetable production area (1572 ha) accounts for about $28.57 \%$ of the total agricultural land area of the district [9]. Vegetable production in the district not only meets the needs of the people in the area but also is an important supply for the needs of the people of Hanoi city.

The use of pesticide products to increase efficiency in vegetable production in Gia Lam district is, therefore, an inevitable need, however, the risks of pesticides in recent years for vegetable farmers have been almost negligible here. Hence, this study focused on investigating the current farmers' reduction practice of pesticide risks in vegetable production in Gia Lam district, Hanoi city, thereby proposing more solutions to further enhance pesticide risk reduction in the near future.

\section{Materials and Methods}

\subsection{Study Site}

The study was carried out in Gia Lam district, Hanoi city, Vietnam. The district is located on the East of the city in the Red River Delta, one of the two important deltas which produce the majority of agricultural products of the country. Gia Lam district had a total of 5503.22 ha of agricultural land, accounting for $47.15 \%$ of the natural area of the whole district; of which land for annual crops was 4294.1 ha (accounting for a high proportion of 78.03\%), whilst the land for perennial crops made up only $12.06 \%$, equivalent to 663.7 hectares and aquaculture land was only 301 ha (11.92\%) [9]. These figures suggest that agriculture plays an important role in the production of the district and the farmers' income is mainly from annual crop production.

Among 20 communes and 2 towns of Gia Lam district, Van Duc and Dang Xa 
communes (as shown in Figure 1) were chosen for this study because they were the two communes with the largest areas of vegetable production in the district, with 221 ha and 130 ha over a total of 740 ha of the district vegetable growing area in the 2020 winter crop. These locations were also representative for areas with highly intensified farming where pesticides application were considerably significant and safe production were dominant (Van Duc commune had 200 ha of safe vegetable production area and Dang Xa commune had 120 ha of safe vegetable production area, together taking account for the largest proportion of the total safe vegetable production area of the district of 380 ha) [10]. Farmers in Van Duc and Dang Xa communes were growing different vegetables, such as cabbages, Chinese cabbage, broccoli, bitter gourd, cove beans, bok choy, and mustard greens, etc. Among which, many were granted the 3 or 4 star OCOP (one commune, one product) certificates of Hanoi city.

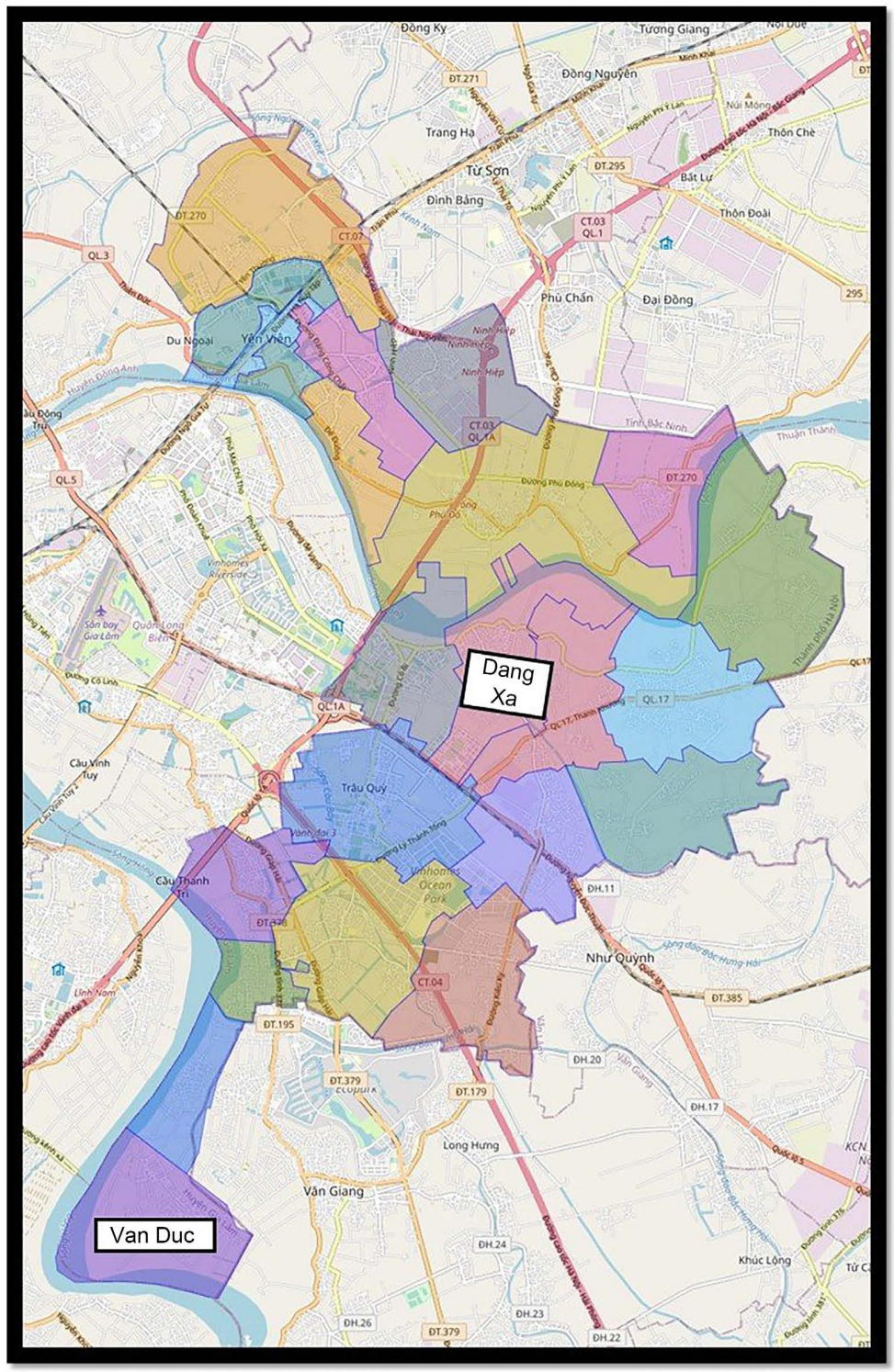

Figure 1. Map of the study area (Gia Lam district, Hanoi city, Vietnam). 


\subsection{Data Collection}

For the purpose of this study, secondary data were collected from books, newspapers, magazines, scientific works, theses, scientific articles related to risks and solutions to reduce pesticide risks around the worlds as well as in Vietnam; and periodic reports and annual summary reports of relevant governmental agencies, especially Gia Lam District People's Committee, Plantation and Plant Protection Station, Economic Departments, and Statistics Department.

Primary data used in the study was collected through direct surveys of 60 vegetable farmers in Van Duc and Dang Xa communes, Gia Lam district using structured questionnaires and direct interviews with state managers related to plant protection in the district using semi-structured questionnaires. The surveys were conducted from March to May 2021.

\subsection{Data Analysis}

The collected data were processed using Excel software. Descriptive statistics and comparative statistics were the main analysis methods used in this study to analyse data after data collection and processing processes.

\section{Results and Discussion}

\subsection{General Information about the Interviewed Farming Households}

Basic information of the interviewed households is presented in Table 1. Farmers in the two studied communes were similar in terms of age, ranging from 41 to 53 years old. All of them were experienced in vegetable farming.

Table 1. Basic information of the interviewed farming households.

\begin{tabular}{|c|c|c|c|c|}
\hline Criteria & Unit & Van Duc commune & Dang Xa commune & Total \\
\hline 1. Total number of respondents & Households & 30 & 30 & 60 \\
\hline 2. Gender & Persons & 30 & 30 & 60 \\
\hline Male & Persons & 20 & 17 & 37 \\
\hline Female & Persons & 10 & 13 & 23 \\
\hline 3. Average age & Years old & 43.56 & 47.13 & 45.35 \\
\hline \multicolumn{5}{|l|}{ 4. Educational levels } \\
\hline Primary school & $\%$ & 23.33 & 26.67 & 28.33 \\
\hline Secondary school & $\%$ & 23.33 & 20 & 21.67 \\
\hline High school & $\%$ & 33.33 & 30 & 28.34 \\
\hline Complementary education & $\%$ & 6.67 & 3.33 & 5 \\
\hline Technician school & $\%$ & 0 & 10 & 5 \\
\hline College & $\%$ & 6.67 & 3.33 & 5 \\
\hline University & $\%$ & 6.67 & 6.67 & 6.67 \\
\hline 5. Average number of members/household & Persons/household & 3.96 & 3.76 & 3.86 \\
\hline 6. Average number of labourers/household & Persons/household & 2.23 & 2.36 & 2.3 \\
\hline
\end{tabular}

Source: Survey result (2021). 
Regarding the gender of the household heads, most of the household heads of the interviewed farming households were male. Out of a total of 60 interviewed households, 37 heads of households were male (61.67\%), 23 heads of households were female (38.33\%). In Van Duc commune, the households with a male head of household accounted for $66.67 \%$, while the ones with a female head of household accounted for only 33.33\%. In Dang Xa commune, the households with a male head made up 56.67\%, while those wiith a female head made up $43.33 \%$. It can be seen that the majority of household heads were male maybe because men tended to be decision makers in the family, deciding their production activities and being more active in applying scientific and technological advances (Table 1).

Regarding the educational level of the household head, the ssurvey data shows that out of a total of 30 surveyed households in each commune, $100 \%$ of the household heads of the surveyed farming households had an educational level of at least primary school. High school degree holders accounted for the highest percentages, with $33.33 \%$ and $30.00 \%$ of the interviewees in Van Duc and Dang Xa communes, respectively. Household heads with secondary education accounted for $23.33 \%$ and $20 \%$ of the surveyed households in Van Duc and Dang Xa communes, respectively. The percentage of household heads with college or university education was low (less than 13\%). The educational level of the household head is important because it reflects the level of awareness, understanding and ability to absorb and apply science and technology to production activities of the farmer household. From the survey results, it can be seen that the heads of households in the two communes had a relatively high level of education. This is an advantage for production activities, applying science and technology to production, absorbing new knowledge into production activities, and implementing effective measures to reduce risks of pesticides by plants of the surveyed households.

On average, the number of household members was 3.86 people/household. The average population of Van Duc commune was 3.96 people/household, higher than Dang Xa commune with 3.76 people/household. The number of laborers per household in Dang Xa commune was higher with 2.36 laborers/household; while in Van Duc commune, this figure was 2.34 laborers/household.

\subsection{The Current Pesticide Use by Vegetable Farmers in Gia Lam District, Hanoi City}

Pesticides were an important input material in vegetable cultivation in Gia Lam district, especially in the two survey communes, Van Duc and Dang Xa. The results of the investigation and field survey show that people in 2 communes Van Duc and Dang Xa currently used 18 main active ingredients with 30 different trade names in vegetable production (Table 2). The most commonly used active ingredients were Permethrin, Abamectin, Spirotetramat, Chlorothalonil, Bacillus Thuringiensis, Emamectin benzoate, Diafenthiuron, Matrine, Azadirachtin, 
Table 2. Commonly used pesticides on vegetables in Van Duc and Dang Xa communes, Gia Lam district.

\begin{tabular}{|c|c|c|c|c|}
\hline No. & Trade names & Active ingredients & Subject to pests/diseases & $\begin{array}{l}\text { Classification } \\
\text { by hazard }\end{array}$ \\
\hline 1 & Pounce 50EC & Permethrin $50 \% \mathrm{w} / \mathrm{w}$ & Leaf-eating caterpillars & \\
\hline 2 & Vitashield gold 600EC & $\begin{array}{l}\text { Alpha Cypermethrin } 50 \mathrm{~g} / \mathrm{L}+\text { Chlorpyrifos } \\
\text { Ethyl } 545 \mathrm{~g} / \mathrm{L}+\text { Indoxacarb } 5 \mathrm{~g} / \mathrm{L}\end{array}$ & Leaf folders and stem borers & $\begin{array}{l}\text { Group II } \\
\text { (Moderately }\end{array}$ \\
\hline 3 & $\begin{array}{l}\text { Abamine } \\
3.6 \mathrm{EC}\end{array}$ & Abamectin $3.6 \%$ & Silkworm, borer, green worm, and thrips & hazadous) \\
\hline 4 & Movento 150OD & Spirotetramat $150 \mathrm{~g} / \mathrm{L}$ & $\begin{array}{l}\text { Jumping beetles, suckers (aphids and } \\
\text { thrips, etc), annd yellow flies }\end{array}$ & \multirow{6}{*}{$\begin{array}{l}\text { Group III } \\
\text { (Slightly } \\
\text { hazadous) }\end{array}$} \\
\hline 5 & Mig 18 207WG & $\begin{array}{l}\text { Azadirachtin } 1.5 \mathrm{~g} / \mathrm{kg}+\text { Chlorfluazuron } 200 \\
\mathrm{~g} / \mathrm{kg}+\text { Emamectin benzoate } 5.5 \mathrm{~g} / \mathrm{kg}\end{array}$ & $\begin{array}{l}\text { Leaf rollers, stem borers, fruit borers, } \\
\text { silkworms, and green caterpillars }\end{array}$ & \\
\hline 6 & Delfin WG & $\begin{array}{l}\text { Bacillus Thuringiensis (Var. Kurstaki): } \\
\text { 32BUI/KG }\end{array}$ & Silkworm, green worm, and armyworm & \\
\hline 7 & Elcarin $0.5 S L$ & Fugous Proteoglycans $0.5 \%$ (w/w) & Wilting and rottening & \\
\hline 8 & Kuraba WP & $\begin{array}{l}\text { Abamectin } 0.1 \%(3.5 \%)+\text { Bacillus } \\
\text { thuringiensis var.kurstaki } 1.9 \%(0.1 \%)\end{array}$ & $\begin{array}{l}\text { Silkworm, green worm, leaf borer, } \\
\text { armyworm, and thrips }\end{array}$ & \\
\hline 9 & Daconil 75WP & Chlorothalonil (min 98\%) & $\begin{array}{l}\text { Powdery mildew, leaf spot, anthracnose, } \\
\text { and downy mildew }\end{array}$ & \\
\hline 10 & Promectin 5.0EC & Emamectin benzoat & Leaf-eating caterpillars & \multirow{5}{*}{$\begin{array}{l}\text { Group IV } \\
\text { (Unlikely to } \\
\text { present acute } \\
\text { hazard) }\end{array}$} \\
\hline 11 & Pegasus 500SC & Diafenthiuron $500 \mathrm{~g} / \mathrm{L}$ & $\begin{array}{l}\text { Jumping beetles, suckers (aphids and } \\
\text { thrips, etc.), and yellow flies }\end{array}$ & \\
\hline 12 & Radiant 60SC & Spinetoram $60 \mathrm{~g} / \mathrm{L}$ & $\begin{array}{l}\text { Smooth-skinned caterpillars, leaf borers, } \\
\text { fruit borers, thrips, silkworms, green } \\
\text { caterpillars, and white butterflies }\end{array}$ & \\
\hline 13 & Cajet-M10 72WP & Cymoxanil 8\% + Mancozeb 64\% & $\begin{array}{l}\text { Pseudoperonospora cubensis, leaf spot, } \\
\text { rust and late blight diseases }\end{array}$ & \\
\hline 14 & Etobon $0.56 \mathrm{SL}$ & Cytokinin (Zeatin) $5.6 \mathrm{~g} / \mathrm{L}$ & $\begin{array}{l}\text { Nematodes, damping-off disease, and } \\
\text { pythium root rot }\end{array}$ & \\
\hline
\end{tabular}

Note: EC, OD, WG, SL, WP, and SC denote the formulation of the pesticides, namely Emulsifiable Concentrate, Oil Dispersion, Water Dispersible Granule, Soluble Liquid, Wettable Powder, and Suspension Concentrate, respectively. Source: Survey result (2021).

Cytokinin (Zeatin), and Bacillus subtilis, etc. The most widely used pesticides in production could be listed as Pounce 50ec, Vitashield gold 600EC, Movento 150OD, Delfin WG, Kuraba WP, Promectin 5.0EC, and Radiant 60SC, etc.

Research results showed that, according to the WHO recommended classification of pesticides by hazard categorizes [10], in vegetable cultivation in Van Duc and Dang Xa communes, farmers mainly used pesticides in Group II (Moderately hazadous), Group III (Slightly hazadous), and Group IV (Unlikely to present acute hazard), whereas pesticides in Group I (Extremely and Highly hazardous) were totally not in use (Table 3). Among these, pesticides belonging to group III accounted for the highest proportion of $51.63 \%$. All of the widely used pesticides were on the list of pesticides issued by Vietnam's Ministry of Agriculture 
Table 3. Structure of commonly used pesticides by farmers in vegetable production in Gia Lam district.

\begin{tabular}{|c|c|c|c|c|}
\hline \multicolumn{2}{|l|}{ Category } & Van Duc commune (\%) & Dang Xa commune (\%) & Whole \\
\hline \multirow{2}{*}{ 1. Origins } & Chemical pesticides & 32.37 & 36.44 & 34.41 \\
\hline & Biological pesticides & 67.63 & 63.56 & 65.60 \\
\hline \multirow{4}{*}{ 2. Hazard levels } & Group I & 0.00 & 0.00 & 0 \\
\hline & Group II & 26.75 & 32.20 & 29.48 \\
\hline & Group III & 54.58 & 48.67 & 51.63 \\
\hline & Group IV & 18.67 & 19.13 & 18.90 \\
\hline \multirow{2}{*}{$\begin{array}{l}\text { 3. Included in the list allowed to } \\
\text { use for rice and cash crops }\end{array}$} & Yes & 100.00 & 100.00 & 100.00 \\
\hline & No & 0.00 & 0.00 & 0.00 \\
\hline
\end{tabular}

Source: Survey result (2021).

and Rural Development. It can be seen that farmers in the study area had the tendency to use less toxic pesticides for their cultivation. It is also essential to further encourage the use of Group IV pesticides to minimize pesticide risks in the future.

\subsection{The Current Application of Pesticide Risk Reduction Measures by Vegetable Farmers in Gia Lam District, Hanoi City}

Conventional pesticides are an integral part of the protection systems in agricultural production [11]. Its use is, hence, inevitable. Farmers in Gia Lam districts strived to reduce their reliance on conventional pesticides and reduce their exposure to pesticides by employing a number of measures as follows:

\subsubsection{Application of Integrated Pest Management (IPM)}

Integrated pest management (IPM) is the ideal method to reduce pesticide use and protect the environment from pollution, helping to ensure food safety and human health [12]. Pest management is achieved directly using a variety of tools, including pesticides, and indirectly through a number of other farming practices; this integrated approach has a positive effect on plant health in general as well as helps to reduce the pesticides needed for the plants [13]. In Gia Lam district, alternative pest and crop protection methods focusing on agroecosystems and integrated pest management had been prioritized for application in vegetable production by farmers in the two surveyed communes (Table 4).

1) Field sanitation: That is an important tactics in IPM which mean cleaning up crop residues and eliminating weeds thoroughly. This helps to reduce the appearance of pests and diseases, thus minimizing early-season spraying. The survey results showed that more than $90 \%$ of the farmers in the two surveyed communes thoroughly cleaned the fields at the beginning of each croppingng season.

2) Taking advantage of natural enemies and parasites. Farmers use Eocanthecona 
Table 4. The current application of alternative pest control methods (IPM) of the vegetable farmers in Gia Lam district.

\begin{tabular}{|c|c|c|c|c|}
\hline \multirow[b]{2}{*}{ Methods } & \multicolumn{2}{|c|}{ Van Duc commune } & \multicolumn{2}{|c|}{ Dang Xa commune } \\
\hline & $\begin{array}{l}\text { Number of } \\
\text { households }\end{array}$ & $\begin{array}{l}\text { Percentage } \\
(\%)\end{array}$ & $\begin{array}{l}\text { Number of } \\
\text { households }\end{array}$ & $\begin{array}{l}\text { Percentage } \\
(\%)\end{array}$ \\
\hline 1. Field sanitation & 28 & 93.33 & 27 & 90 \\
\hline 2. Taking advantage of natural enemies and parasites & 11 & 36.67 & 9 & 30 \\
\hline 3. Crop rotation & 14 & 46.67 & 13 & 43.33 \\
\hline 4. Choosing the proper plant varieties & 11 & 36.67 & 12 & 40 \\
\hline 5. Applying technical advances into production & 18 & 60 & 16 & 53.33 \\
\hline -Methyl Eugentol bait traps to eliminate fruit flies & 12 & 40 & 15 & 50 \\
\hline -Yellow sticky traps to trap silkworms & 14 & 46.67 & 16 & 53.33 \\
\hline -Green sticky traps to trap thrips & 7 & 23.33 & 6 & 20 \\
\hline -Using the Passlite coating & 4 & 13.33 & 5 & 16.67 \\
\hline
\end{tabular}

Source: Survey result (2021).

furcellata bugs, parasitic wasps, and beetles, etc. (these species are natural enemies of pests such as green planthoppers, leafhoppers, butterflies and young caterpillars of stem borers, and greenworms, etc.) to eliminate pests, thereby helping to reduce the amount of pesticides used in farming and limiting the risks of pesticides. More than $30 \%$ of the interviewees used natural enemies and parasites in their production to reduce the use of pesticides.

3) Crop rotation: Farmers have formed the habit of diversifying vegetable varietiess, alternating crop varieties throughout the years, thereby limiting the proliferation of pests, thus limiting the use of pesticides. This is a relatively important measure in preventing pests and diseases of the farmers in the study area, with about $43.33 \%$ to $46.67 \%$ of the interviewed households in each commune applying this method as a solution. reduce the use of pesticides.

4) Choosing proper plant varieties. People have paid attention to choose the varieties that are disease-free, resistant to pests and diseases, and certified by the seed quality testing agency. This helps to reduce the amount of pesticides used on crops in the area quite effectively. The rate of applying plant variety orientation in the two surveyed communes was about $40 \%$ of the interviewed households (mainly and with cabbage and cucumber).

5) Applying technical advances into production: There were $60 \%$ of households in Van Duc commune and $53.33 \%$ of households in Dang Xa commune that implemented models of technical advances including Methyl Eugentol bait traps to eliminate fruit flies, yellow sticky traps to trap silkworms, green sticky traps to trap thrips, and sweet and sour bait traps to kill insects, etc. to prevent and control pests and diseases, especially putting the Passlite coating model into testing to minimize the use of pesticides.

\subsubsection{Application of Biological Pesticides}

Biological pesticides, in general, have many advantages over conventional pesticides [14] [15]. Biological pesticides are becoming more and more popular around 
the world by being a safer tactic in the management of pests and diseases for the crops whilst having significantly lower risks to not only humans but also the environment [16]. Using biological pesticides and pesticide products with low toxicity and high efficiency in pest control but safer for humans and the environment is one of the important risk reduction measures.

The survey results show that the proportion of biological pesticides in the pesticide structure used in Van Duc commune was 67.63\%, this rate in Dang Xa commune was $63.56 \%$ (higher than the rate of chemical pesticides) (Table 2). In which, the most popular were pesticides of Group III (accounting for more than $50 \%$ of the structure of pesticides). This is the result of the careful guidance from technical staff specialized in plant protection, cooperative staff and thanks to active participation in the farmer groups.

Most common biological pesticides applied in vegetable cultivation in the two communes were those containing active ingredients such as Bacillus Thuringiensis, Emamectin benzoate, Diafenthiuron, Matrine, Azadirachtin, Cytokinin (Zeatin), and Bacillus subtilis, etc. All of these pesticides were included in the list allowed to be used by the Vietnam's Ministry of Agriculture and Rural Development as well as the list of pesticides recommended for use prepared by the Plantation and Plant Protection Station of Gia Lam district and sold in pesticide stores in the study area.

\subsubsection{Application of Pesticides According to the 4-Right Pesticide Use Principles}

The application of pesticides, especially of the improper pesticides and improper doses applied, poses a dominant threat to the farmers who apply the pesticides on the fields [17]. Pesticide use principle is important since pesticide risks can be avoided or reduced if farmers understand and practice the principle well. The 4-right principles in the use of pesticides was officially legalized in Vietnam in 2015. It is one of the most important principles in plant protection and quarantine activities in Vietnam [18].

In the two surveyed communes, the majority of farmers understood and practiced quite well in accordance with the 4-right principle: When pests and diseases have reached the threshold, farmers use pesticides in compliance with the instructions of specialized agencies, using pesticides according to the 4-right principles: "RIGHT pesticides for the right crop, RIGHT dose and concentration, RIGHT time of application and RIGHT methods of application".

Specifically, according to the survey results with the Plantation and Plant Protection Station of Gia Lam district on the practice of using pesticides on vegetables of farmers in 2 Van Duc commune and Dang Xa, there were about 86.67\% of the farming households in Van Duc commune and $83.33 \%$ of households in Dang Xa commune practiced spraying according to the 4-right principle. People chose the right pesticides according to the type of pests and diseases, did not use pesticides of unknown origin, choose pesticides on the list of pesticides allowed to use, mainly on the list of recommended pesticides prepared by the District Plantation and Plant Protection Station and the cooperatives in the locality. 
Thanks to the guidance and timely advice of technical staff, most farmers in the study area sprayed at the time when the pest was easily destroyed, reached the threshold, sprayed when it was cool and windless. The spraying process of households followed the instructions on the labels, within the recommended dosage and concentration range. Pesticides were also mixed according to the instructions of the technicians, it was very rare for farmers to arbitrarily mix them.

Besides that, about $60 \%$ of households have paid attention to alternating pesticides in use, thereby limiting the phenomenon of pesticide resistance and resistance of pests and diseases. This was possible thanks to the timely advice of technical staff as well as the owners of local drug stores. Every year, at the beginning of each cropping season, the staff of the District Cultivation and Plant Protection Station make a list of pesticides recommended for use in production for each crop for the farmers, which is shown by visual images and distributed to each commune, each cooperative to promptly advise and provide recommendations to people.

\subsubsection{Application of Labour Protection While Spraying Pesticides}

Protective equipment is again an important solution to pesticide risk reduction [19]. Using labour protection when spraying contributed to the minimization of the exposure to pesticides during use, thereby minimizing the risks of pesticides for direct users, the farmers.

The survey results at Van Duc commune and Dang Xa showed that most the majority of farmers were aware of and habitually using protective equipment during spraying (Table 5). Specifically, over $83 \%$ of people regularly used labor protection while spraying. Over $96 \%$ used masks, over $60 \%$ used gloves, over $73 \%$ wore boots, over $96 \%$ of people wear hats/caps, over $46 \%$ wore eyeglasses, only about $10 \%-16.67 \%$ of people used a raincoat while spraying (Table 5).

\subsubsection{Application of Treatment Techniques after Spraying}

Survey results show that the majority of farmers in Van Duc and Dang Xa communes in Gia Lam district consciously collected bottles and packages of pesticides after using them to the right places as regulated. Rarely the farmers threw away pesticide bottles and packages at the yards at the banks of the fields, or rivers, streams and ponds, causing water pollution, soil and air pollution. Table 6 shows that about $80 \%$ of households in Van Duc and Dang Xa communes collected drug bottles and packages to the storage tanks in accordance with regulations (summarizing results of interviews with the officials of the Cultivation and Plant Protection Station of Gia Lam district, 2021). Most farmers understood and formed the habit of not burning pesticide containers, but collecting them to the dumping tanks according to regulations.

Two communes, Van Duc and Dang Xa, important safe vegetable granaries of Hanoi city, have also invested in building a system of cement tanks containing pesticide packaging in 5 safe vegetable production areas to create favorable conditions for the farmer households to fulfill the commitment of keeping the field clean implemented by the District People's Committee and the cooperatives. 
Table 5. Application of labor protection while spraying of the vegetable farmers in Gia Lam district.

\begin{tabular}{|c|c|c|c|c|c|c|c|}
\hline \multirow[b]{2}{*}{ Criteria } & & \multicolumn{2}{|c|}{ Van Duc commune } & \multicolumn{2}{|c|}{ Dang Xa commune } & \multicolumn{2}{|c|}{ Whole } \\
\hline & & $\begin{array}{l}\text { Number of } \\
\text { households }\end{array}$ & $\begin{array}{c}\text { Percentage } \\
(\%)\end{array}$ & $\begin{array}{l}\text { Number of } \\
\text { households }\end{array}$ & $\begin{array}{c}\text { Percentage } \\
(\%)\end{array}$ & $\begin{array}{l}\text { Number of } \\
\text { households }\end{array}$ & $\begin{array}{l}\text { Percentage } \\
\quad(\%)\end{array}$ \\
\hline \multirow{2}{*}{$\begin{array}{l}\text { 1. The frequency of using labor } \\
\text { protection when spraying }\end{array}$} & -Often & 26 & 86.67 & 25 & 83.33 & 51 & 85 \\
\hline & -Sometimes & 4 & 13.33 & 5 & 16.67 & 9 & 15 \\
\hline \multirow{6}{*}{ 2. Types of labor protection } & -Face masks & 30 & 100 & 29 & 96.67 & 59 & 98.33 \\
\hline & -Gloves & 18 & 60 & 19 & 63.33 & 37 & 61.67 \\
\hline & -Boots & 22 & 73.33 & 25 & 83.33 & 47 & 78.33 \\
\hline & -Hats/Caps & 30 & 100 & 29 & 96.67 & 59 & 98.33 \\
\hline & -Glasses & 14 & 46.67 & 15 & 50 & 29 & 48.33 \\
\hline & -Raincoat & 5 & 16.67 & 3 & 10 & 8 & 13.33 \\
\hline
\end{tabular}

Source: Survey data (2021).

Table 6. Application of different treatment techniques after spraying of the vegetable farmers in Gia Lam district.

\begin{tabular}{|c|c|c|c|c|c|c|c|}
\hline \multirow{2}{*}{\multicolumn{2}{|c|}{ Treatment techniques after spraying }} & \multicolumn{2}{|c|}{ Van Duc commune } & \multicolumn{2}{|c|}{ Dang Xa commune } & \multicolumn{2}{|l|}{ Total } \\
\hline & & \multirow{2}{*}{$\begin{array}{l}\text { Number of } \\
\text { households }\end{array}$} & \multirow{2}{*}{$\begin{array}{l}\text { Percentage } \\
(\%) \\
80\end{array}$} & \multirow{2}{*}{$\begin{array}{l}\begin{array}{l}\text { Number of } \\
\text { households }\end{array} \\
27\end{array}$} & \multirow{2}{*}{$\begin{array}{l}\text { Percentage } \\
(\%) \\
90\end{array}$} & \multirow{2}{*}{$\begin{array}{l}\begin{array}{l}\text { Number of } \\
\text { households }\end{array} \\
51\end{array}$} & \multirow{2}{*}{$\begin{array}{l}\text { Percentage } \\
(\%) \\
85\end{array}$} \\
\hline 1. Place of & Regulated places & & & & & & \\
\hline $\begin{array}{l}\text { dumping the } \\
\text { pesticide }\end{array}$ & Dumping site on the fields & 5 & 16.67 & 2 & 6.67 & 7 & 11.67 \\
\hline $\begin{array}{l}\text { bottles and } \\
\text { packages }\end{array}$ & Any place convenient & 1 & 3.33 & 1 & 3.33 & 2 & 3.33 \\
\hline \multirow{5}{*}{$\begin{array}{l}\text { 2. Handling } \\
\text { of excess } \\
\text { pesticides }\end{array}$} & Spraying it all & 7 & 23.33 & 10 & 33.33 & 17 & 28.33 \\
\hline & Pouring into the ditch & 3 & 10 & 0 & 0 & 3 & 5 \\
\hline & Dumping to the ponds and lakes & 2 & 6.67 & 1 & 3.33 & 3 & 5 \\
\hline & Spraying other plants/crops & 3 & 10 & 2 & 6.67 & 5 & 8.33 \\
\hline & Dumping at the regulated places & 15 & 50 & 17 & 56.67 & 32 & 53.33 \\
\hline \multirow{3}{*}{$\begin{array}{l}\text { 3. Place of } \\
\text { cleaning the } \\
\text { spraying tools }\end{array}$} & Any place convenient & 6 & 20 & 7 & 23.33 & 13 & 21.67 \\
\hline & Regulated places & 24 & 80 & 23 & 76.67 & 47 & 78.33 \\
\hline & Do not clean the spraying tools & 0 & 0 & 1 & 3.33 & 1 & 1.67 \\
\hline \multirow{2}{*}{$\begin{array}{l}\text { 4. Keeping } \\
\text { spraying tanks }\end{array}$} & Far away from houses and barns & 22 & 73.33 & 24 & 80 & 46 & 76.67 \\
\hline & Close to houses and barns & 8 & 26.67 & 6 & 20 & 14 & 23.33 \\
\hline \multirow{2}{*}{$\begin{array}{l}\text { 5. Rinsing the } \\
\text { mouth after } \\
\text { spraying }\end{array}$} & Yes & 26 & 86.67 & 25 & 83.33 & 51 & 85 \\
\hline & No & 4 & 13.33 & 5 & 16.67 & 9 & 15 \\
\hline \multirow{2}{*}{$\begin{array}{l}\text { 6. Using eye } \\
\text { drops after } \\
\text { spraying }\end{array}$} & Yes & 19 & 63.33 & 16 & 53.33 & 35 & 58.33 \\
\hline & No & 11 & 36.67 & 14 & 46.67 & 25 & 41.67 \\
\hline $\begin{array}{l}\text { 7. Keeping } \\
\text { spraying clothes }\end{array}$ & Yes & 26 & 86.67 & 28 & 93.33 & 54 & 90 \\
\hline separately & No & 4 & 13.33 & 6 & 20 & 10 & 16.67 \\
\hline
\end{tabular}

Source: Survey result (2021). 
In addition, the farmers of the two surveyed communes also formed a habit of cleaning spraying tools after spraying-washing the pesticide spray tanks both inside and outside with soap, disassembling each set part separately, opening the nozzle, draining the water and letting the tanks dry off, and storing them in a warehouse separate from houses and barns. The proportion of farmers cleaning the pesticide spray tanks after spraying at Van Duc and Dang Xa communes reached $100 \%$ of the surveyed households. The percentages of households that kept spray tools away from houses and barns in Van Duc and Dang Xa communes were $73.33 \%$ and $80 \%$, respectively (Table 6 ).

For the excess pesticides after spraying, most farmers poured them into the containers in accordance with regulations. This percentage of surveyed households pouring excess pesticides to the regulated places reached 50\% and 56.67\% in Van Duc and Dang Xa communes, respectively. There was no case that farmers dumped the excess pesticides in the ditches or near water sources.

After spraying pesticides, most of the surveyed farmers practiced personal hygiene measures such as rinsing the mouth ( $85 \%$ of the interviewed households), using eye drops (58\% of the interviewed households) and keeping the spraying clothes separate from other clothes (90\% of the interviewed households).

It can be seen that, in general, farmers in the two surveyed communes performed the treatment measures after spraying relatively well as a solution to reduce the risks of pesticides in their production.

\section{Conclusions}

Vegetable farmers in Gia Lam district, Hanoi city, made significant efforts to reduce the risks of pesticides by applying a number of risk reduction measures in their agricultural production, including using alternative pest management solutions (IPM) such as field sanitation, crop rotation, exploitation of natural enemies and parasites, crop selection orientation, and application of technical advances; using biological pesticides (over 63\%); using pesticides properly according to the 4-right pesticide use principles (over $80 \%$ of the households); using labor protection while spraying pesticides; and applying treatment techniques after spraying.

In the coming years, to further reduce the risks of pesticides in vegetable production of farmers in Gia Lam district, Hanoi city, it is of importance to focus on implementing a number of solutions as follows: 1) Strengthening governmental management for pesticides (increasing human resources for the plant protection departments to manage pesticides at the commune level, strengthening management of the collection and treatment of pesticide packaging after use and after collection at the storage tanks, and establishing a commune-level pesticide management board); 2) Strengthening training and communication on pesticide risks and pesticide risk reduction; 3) Strengthening support and supply of biological pesticides to farmers; 4) Strengthening activities of PGS groups in pesticide risk reduction; 5) Strengthening the application of technical measures to 
reduce exposure to pesticides for farmers; and 6) Encouraging more farmers to participate in health insurance.

\section{Conflicts of Interest}

The authors declare no conflicts of interest regarding the publication of this paper.

\section{References}

[1] Mahmood, I., Imadi, S.R., Shazadi, K., Gul, A. and Hakeem, K.R. (2016) Effects of Pesticides on Environment. In: Hakeem, K., Akhtar, M. and Abdullah, S., Eds., Plant, Soil and Microbes, Springer, Cham, 253-269. https://doi.org/10.1007/978-3-319-27455-3 13

[2] Cooper, J. and Dobson, H. (2007) The Benefits of Pesticides to Mankind and the Environment. Crop Protection, 26, 1337-1348. https://doi.org/10.1016/j.cropro.2007.03.022

[3] Damalas, I.C.A. and Eleftherohorinos, I.G. (2011) Pesticide Exposure, Safety Issues, and Risk Assessment Indicators. International Journal of Environmental Research and Public Health, 8, 1402-1419. https://doi.org/10.3390/ijerph8051402

[4] Hoang, B.T. (2009) Limiting the Abuse of Pesticides: For Women's Health and a Clean Agriculture. National Political Publishing House, Hanoi, 698 p. (In Vietnamese)

[5] Jaga, K. and Dharmani, C. (2006) Ocular Toxicity from Pesticide Exposure: A Recent Review. Health and Preventive Medicine, 11, 102-107. https://doi.org/10.1265/ehpm.11.102

[6] Polyxeni, N.S., Sotirios, M., Chrysanthi, K., Panagiotis, S. and Luc, H. (2016) Chemical Pesticides and Human Health: The Urgent Need for a New Concept in Agriculture. Frontiers in Public Health, 4, Article No. 148. https://doi.org/10.3389/fpubh.2016.00148 https://www.frontiersin.org/article/10.3389/fpubh.2016.00148

[7] Gerd, W. (2007) Basics of Pesticide Risk Reduction. Regional Workshop on Curriculum Development for Pesticide Risk Reduction, Phnom Penh, 4-7 December 2007.

[8] FAO (Food and Agriculture Organization of the United Nations) (2013) Empowering Farmers to Reduce Pesticide Risks. FAO Regional IPM/Pesticide Risk Reduction Programme in Asia, FAO Regional Office for Asia and the Pacific, Bangkok. https://www.researchgate.net/publication/259080275 Empowering Farmers to Re duce Pesticide Risks

[9] Gia Lam District Statistics Office (2021) Gia Lam District Statistical Yearbook for the Period 2015-2020. Gia Lam District Statistics Office, Gia Lam. (In Vietnamese)

[10] World Health Organization (2020) The WHO Recommended Classification of Pesticides by Hazard and Guidelines to Classification 2019. World Health Organization, Geneva. https://apps.who.int/iris/handle/10665/332193

[11] Lamichhane, J.R. (2017) Pesticide Use and Risk Reduction in European Farming Systems with IPM: An Introduction to the Special Issue. Crop Protection, 97, 1-6. https://doi.org/10.1016/j.cropro.2017.01.017

[12] El-Motaleb, F.A. (2019) Integrated Pest Management. Open Access Journal of Environmental and Soil Sciences, 2, 239.

[13] Quarcoo, F., Bonsi, C., Tackie, D.N.O., Hill, W.A., Wall, G. and Hunter, G. (2017) Economies of Scale in Integrated Pest Management in Vegetable and Fruit Produc- 
tion. Professional Agricultural Workers Journal, 5, Article No. 7.

[14] Kaya, H.K. and Lacey, L.A. (2007) Introduction to Microbial Control. In: Lacey, L.A. and Kaya, H.K., Eds., Field Manual of Techniques in Invertebrate Pathology, 2nd Edition, Springer, Dordrecht, 3-7. https://doi.org/10.1007/978-1-4020-5933-9 1

[15] Kaya, H.K. and Vega, F.E. (2012) Scope and Basic Principles of Insect Pathology. In: Vega, F.E. and Kaya, H.K., Eds., Insect Pathology, 2nd Edition, Academic Press. Cambridge, 1-12. https://doi.org/10.1016/B978-0-12-384984-7.00001-4 https://www.researchgate.net/publication/286177612 Scope and Basic Principles of Insect Pathology

[16] Kumar, S. and Singh, A. (2015) Biopesticides: Present Status and the Future Prospects. Journal of Fertilizers and Pesticides, 6, Article No. e129. https://doi.org/10.4172/2471-2728.1000e129

[17] Eltyeb, A., Mergani, E., Khalid, O., Shareef, T. and Abbakar, K. (2020) The Role of Agricultural Extension in Decentralizing the Sensitivity of Vegetable Farmers to the Risk of Residual Pesticide Effects. Agricultural Sciences, 11, 722-729. https://doi.org/10.4236/as.2020.118047

[18] Do, M.S., Tran, T.N.T and Vu, T.T.M. (2020) Compliance with the "4 Right" Principle in Pesticide Using of Decorative Tree Planters in Nam Phong Village, Nam Dinh Province, Vietnam. International Journal of Scientific and Research Publications, 10, 24-29. https://doi.org/10.29322/IJSRP.10.07.2020.p10304

[19] Phung, T.D., Connell, D., Miller, G., Rutherford, S. and Chu, C. (2013) Needs Assessment for Reducing Pesticide Risk: A Case Study with Farmers in Vietnam. Journal of Agromedicine, 18, 293-303. https://doi.org/10.1080/1059924X.2013.826605 